\title{
Successful closure of esophagomediastinal fistula with endoclips and an endoloop after endoscopic submucosal dissection
}
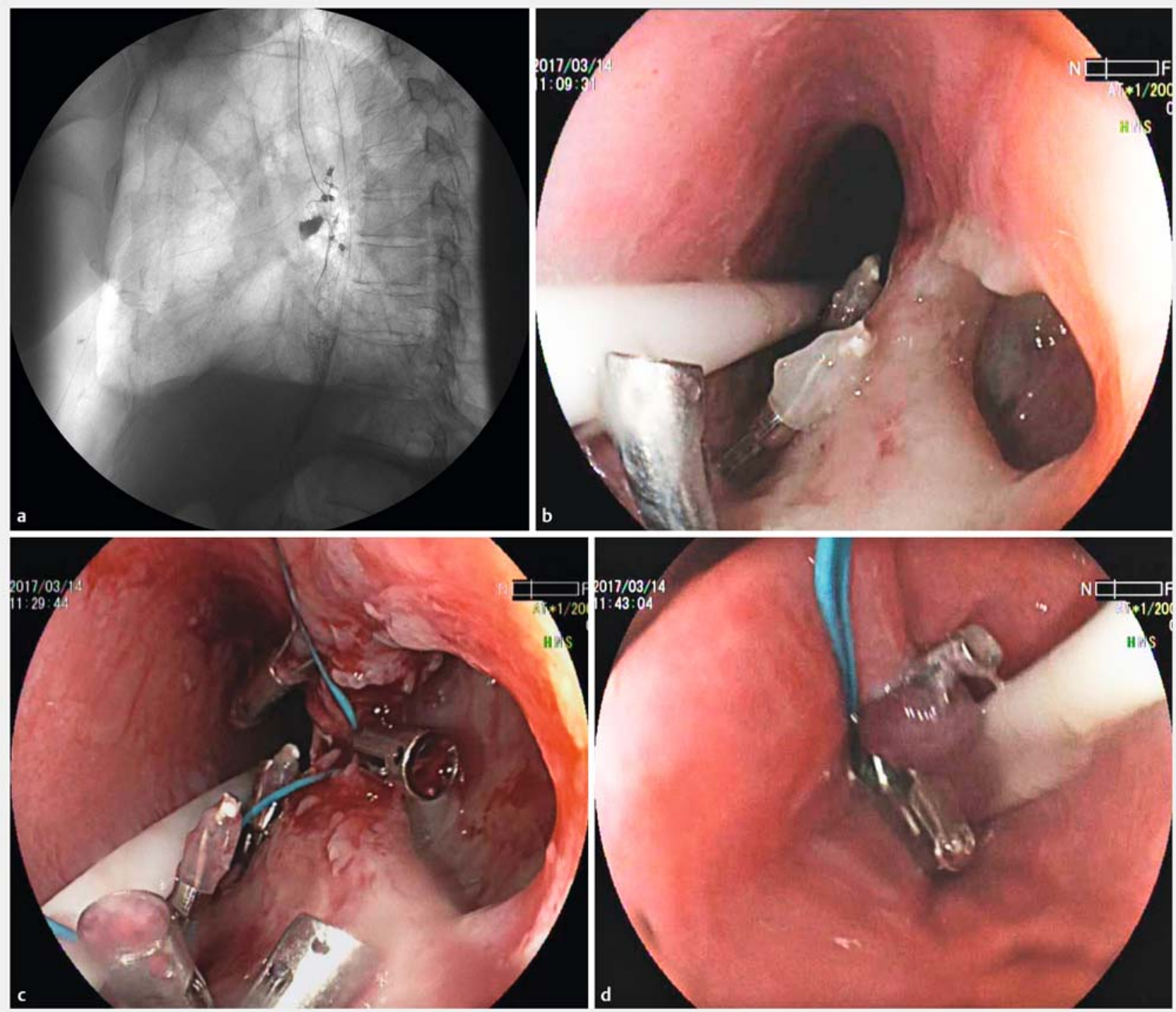

- Fig. 1 Esophagomediastinal fistula following endoscopic submucosal dissection. a Esophagography with a water-soluble contrast agent suggested the presence of an esophagomediastinal fistula. b The orifice of the fistula. c An open endoloop was placed around the orifice of the fistula and anchored into the margin by endoclips. $\mathbf{d}$ The endoloop was tightened and the esophagomediastinal fistula was closed.

Perforation, bleeding, mediastinal emphysema, and postoperative stricture are the most common complications associated with esophageal endoscopic submucosal dissection (ESD) [1]. However, though rare, esophagobronchial fistula or esophagomediastinal fistula can also develop after ESD. Conventional treatments of esophageal fistula include surgery, esophageal covered stent implantation, and other endoscopic methods involving the use of endoclips or fibrin glue [2-5].
A 65-year-old man with esophageal high grade intraepithelial neoplasia underwent ESD at our hospital. Following submucosal dissection, multiple-site damage of the muscular layer was found at the mucosal defect. Endoclips (ROCC-D26-195; Micro-Tech [Nanjing] Co., Ltd., 


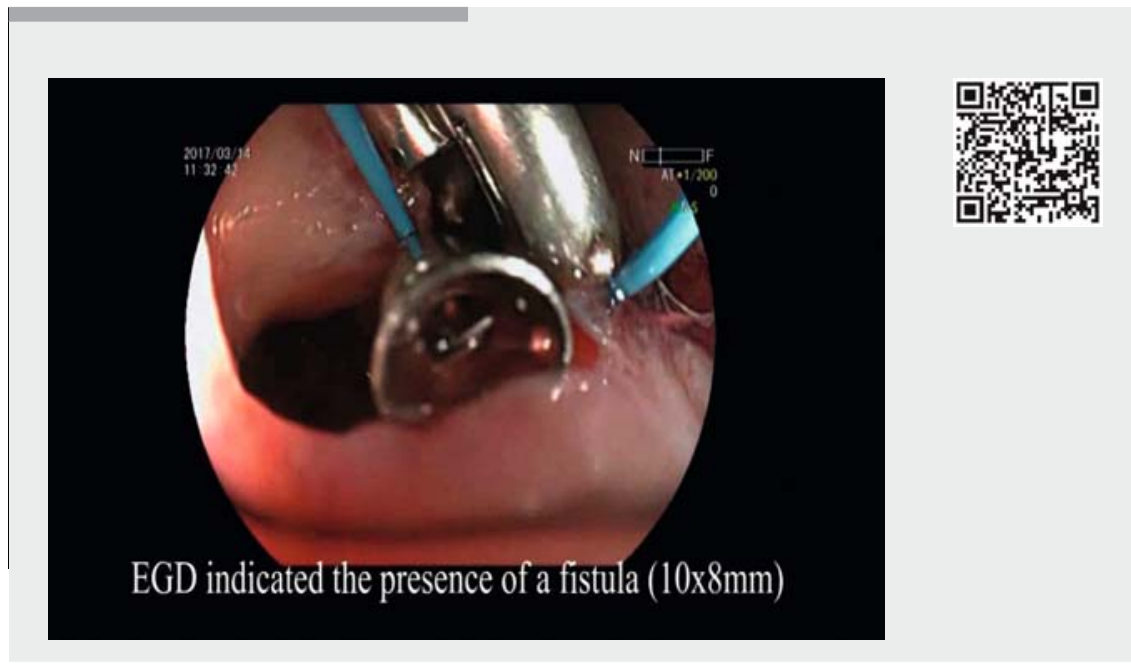

Video 1 Endoscopic treatment for esophagomediastinal fistula with endoclips and an endoloop after endoscopic submucosal dissection.

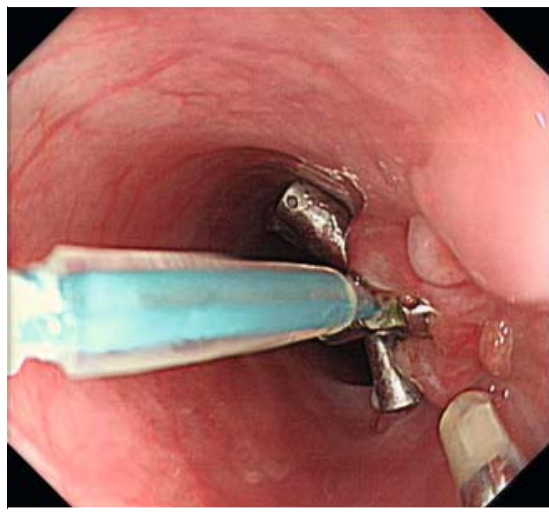

- Fig. 2 Esophagogastroduodenoscopy revealed complete healing of the fistula, with residual endoclips and endoloop and formation of granulation tissue.
Nanjing, China) were used to close the defective muscularis.

The patient developed cough with sputum and chest pain on the day after ESD. Esophagography using a water-soluble contrast agent suggested the presence of a large esophagomediastinal fistula $(24 \times 16 \mathrm{~mm})$ ( $>$ Fig.1a). The patient's symptoms were controlled after ambrosia and use of a broad-spectrum antibiotic. A repeat esophagography 4 days later revealed that the fistula had not significantly decreased in size. Esophagogastroduodenoscopy (EGD) indicated the presence of a fistula $(10 \times 8 \mathrm{~mm})$ on the

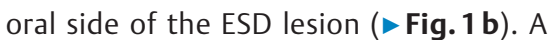
30-mm open endoloop (MAJ-254; Olympus Medical Co., Tokyo, Japan) was placed around the fistula orifice and anchored using five endoclips (> Fig.1 c). Subsequently, the endoloop was tightened and then released ( $>$ Fig. $\mathbf{1} \mathbf{d}$, $\triangleright$ Video $\mathbf{1}$ ). Following this successful closure of the esophagomediastinal fistula, a jejunal tube was placed.
Esophagographic examination 2 days after the endoscopic fistula closure showed no extravasation of contrast. EGD performed 2 months later indicated complete healing of the fistula, with residual endoclips and endoloop and formation of granulation tissue ( $\triangleright$ Fig. 2 ).

To the best of our knowledge, this is the first report of an esophagomediastinal fistula after ESD closed by tightening an endoloop anchored by endoclips. Further studies will be necessary to demonstrate the general applicability of this method to other segments of the gastrointestinal tract.

\section{Endoscopy_UCTN_Code_CPL_1AH_2AG}

\section{Competing interests}

None
The authors

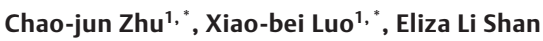
Fong $^{2}$, Zhen Wang ${ }^{1}$, Yang Bai ${ }^{1}$, Ze-long Han ${ }^{1}$, Side Liu ${ }^{1}$

1 Guangdong Provincial Key Laboratory of Gastroenterology, Department of Gastroenterology, Nan fang Hospital, Southern Medical University, Guangzhou, China

2 Department of Biomedical Engineering, National University of Singapore, Singapore

Corresponding author

\section{Ze-long Han, MD}

Guangdong Provincial Key Laboratory of Gastroenterology, Department of Gastroenterology, Nanfang Hospital, Southern Medical University, Guangzhou 510515, China Fax: +86-020-87280770 hzl198886@163.com

* These authors contributed equally to this work. 


\section{References}

[1] Repici A, Hassan C, Carlino A et al. Endoscopic submucosal dissection in patients with early esophageal squamous cell carcinoma: results from a prospective Western series. Gastrointest Endosc 2010; 71: 715 721

[2] Abe S, Oda I, Mori G et al. Complete endoscopic closure of a large gastric defect with endoloop and endoclips after complex endoscopic submucosal dissection. Endoscopy 2015; 47 (Suppl. 01): E374-E375

[3] Ahn JY, Jung HY, Choi JY et al. Benign bronchoesophageal fistula in adults: endoscopic closure as primary treatment. Gut Liver 2010; 4: 508-513
[4] Ivekovic H, Rustemovic N, Brkic T et al. The esophagus as a working channel: successful closure of a large Mallory-Weiss tear with clips and an endoloop. Endoscopy 2011; 43 (Suppl. 02): E170

[5] Ogunmola N, Wyllie R, McDowell K et al. Endoscopic closure of esophagobronchial fistula with fibrin glue. J Pediatr Gastroenterol Nutr 2004; 38: 539-541

\section{Bibliography}

DOI https://doi.org/10.1055/s-0043-124181

Published online: 8.2.2018

Endoscopy 2018; 50: E92-E94

(c) Georg Thieme Verlag KG

Stuttgart · New York

ISSN 0013-726X
ENDOSCOPY E-VIDEOS

https://eref.thieme.de/e-videos

回的 Endoscopy E-Videos is a free access online section, reporting 国: on interesting cases and new techniques in gastroenterological endoscopy. All papers include a high quality video and all contributions are freely accessible online.

This section has its own submission website at

https://mc.manuscriptcentral.com/e-videos 